\title{
LINEAR INFRASTRUCTURES THAT CHARACTERIZE A PAST LAND MANAGEMENT: THE MONTAGNOLA SENESE DRY STONE WALLS. A METHODOLOGICAL APPROACH OF ANALYSIS
}

\author{
Emanuele Vazzano, Amato Bonavita, Paolo Pellegrini
}

\section{Introduction}

This paper approaches the study of a land analysis method, aiming at the knowledge of linear dry stone infrastructures related to an earlier landscape planning in the Montagnola Senese, a hilly area a few kilometers away from Siena.

The investigation area is characterized by mixed woodlands of deciduous trees, mostly oaks, with minor interspersed agricultural open areas, which are now next to decline, due to the abandonment of rural activities regularly performed until recently.

Because of its natural features and its historical and cultural values, this area has been identified and recognized both as "Site of Community Importance (SCI)" according to the EEC regulation 92/43, and as "Site of Regional Importance" (SIR) according to Tuscany RL 56/2000.

The history of the settlement system shows a crystallized condition that has persisted for many centuries. Both the housing structure and land system, until a short time ago, were characterized by a spread settlement system not concentrated in large built-up areas - without any unused gaps between rural activities in the countryside, with interspersion of woods and fields that ensured self-sufficiency of peasant households in all parts of the country. The origin of most of the buildings that make up this estate network is very old, according to [Cammarosano 1983], as evidenced by documents dating back to the tenth century. The abandonment of many estate complexes and the related reduction of the rural population, the decline of sharecropping, the establishment of modern working relationships and up-to-date business systems have meant that, in less than 50 years, the struc-

Paper received 26.05.2010; accepted 15.12.2010

Dr. Emanuele Vazzano, Phd student, Phd. Amato Bonavita, Prof. Paolo Pellegrini, Associate Professor, Department of Agricultural and Forest Economics, Engineering, Sciences and Technologies (DEISTAF), University of Firenze, Via San Bonaventura, 13 - 50145 Firenze, Italy, e-mail of corresponding author: paolo.pellegrini@unifi.it; phone $+39(0) 553288623$. ture of a territory which had remained steady for centuries has now suffered great changes [Casanova 2007].

In the Montagnola, in addition to the buildings of the holdings, we can still find many linear infrastructures built of dry stone such as self-standing walls, paved roads - mainly with roadside walls, and terrace sustaining walls. These artefacts provide an example of how the rural area was organized in the course of history, thanks to the abundant stone material found on site.

Most of these structures are now in condition of neglect, out of use in today's agricultural-forest practices, mainly not represented on current maps even the ones at a larger representation scale.

In Italy most researchers interested in dry stone infrastructures have mainly focused on the recovery of terrace-sustaining walls [Baldeschi 2008; Di Fazio 2008; Sangiorgi 2006]. Much attention was also paid to the study of historic roads [Stopani 2004].

It is worth noting the particular situation of Sardinia, where the origin of most free-standing walls seems to be related to a law of the early XIX century, referred to as the Law on enclosing, which allowed individuals to enclose their land [Guidetti 1990].

In our country, however, there is a lack of interest in linear infrastructures like self-standing walls. Abroad, conversely, we note that the interest in this type of artefacts is much greater: in some countries associations have been established which deal with the enhancement and restoration of minor rural works built of dry stone (such as British Trust for Conservation Volunteers BTCV; The Dry Stone Walls Association of Australia DSWAA; The Dry Stone Wall Association of Canada DSWAC; The dry-Stone masonry institute of America, Dry Stone Conservancy DSC [Murray-Wooley 1992] ).

The analysis is intended as a first step to determine whether and under what conditions, these walls could now serve a function for both individual property owners and farmers operating in this land. In that case the scheduled maintenance and restoration, currently implemented, would not be reduced to either historical-cultural or wildlife significance. It could also car- 
ry out a positive function on the productive activities [Sangiorgi 2008] of the farms that, in turn, play a focal role in the safeguarding of the landscape in rural areas [Monti 2006].

The objectives of this study are therefore, both a definition of a methodology for the characterization of self-standing walls, and a preliminary evaluation through the analysis of their distribution- of which functions they performed in the past land management.

\section{Overview and significance of the proposed methodology}

Whereas the origin of the artefacts which the research is dealing with, is still uncertain, thus not attributable to a particular historical period, we have supposed that wall lines might have a relationship with the boundaries of land parcels drawn on the maps of the Catasto Geometrico Toscano in the early nineteenth century, as either property ownership or land use boundaries.

In a GIS environment, the methodology developed involves comparing the wall lines and the territorial structure which can be reconstructed by a spatial analysis of the historical cadastral documentation. In order to reconstruct this structure a Land Information System (LIS) was built in which we placed data layers derived from computerization of cadastral material relevant to the investigation area and the data surveyed during fieldwork.

The Land information system of the study area was designed and developed by the GIS package. Land features (height contour lines, hydrographs, place names, administrative boundaries, roads, etc.) were included and georeferenced within a geographic database, as well as data layers later developed from the digitized cadastral maps, and the ones obtained from data surveyed by fieldwork.

Spatial data were referenced to the Gauss Boaga Roma40 coordinate reference system. These data were complemented with recent orthorectified aerial photos.

Then we proceeded to a historic-functional analysis of the self-standing dry stone walls by comparing the reconstructed historical territorial landscape structure with the spatial distribution of walls in a test area.

\subsection{Digital acquisition of data of the Leopoldian cadastre}

The works of the Leopoldian cadastre were used to draw the First Tuscany Geometric map, which was realized under the careful direction of the astronomer Giovanni Inghirami and completed in 1829. Tuscany was divided into communities, sections and parcels. The topographic survey of each community was linked to the results of a secondary triangulation, and this in turn to a primary one to assemble the General map [Biagioli 1979; Cantile 2008]. The cadastre was designed to detect real estate for tax imposition. Information on the surface area measured in square arms, on ownership, and on type of ownership (herein called "Land Use") was collected and listed in special registers, termed "Tavole Indicative", for each parcel measured in the field and reported by experts in the sections representing each community. [Biagioli 1979; Carnasciali 1989]. A detailed description of the techniques, used by old inventory engineers, is available in "Istruzioni per gl'ispettori ed i geometri del Nuovo Catasto Toscano, 1821"(Instructions to inspectors and surveyors of the new Tuscan Cadastre, 1821), preserved in the State Archive of Siena.

Until recently, scholars used data in the historical cadastral registers mainly to analyze the settlement system, rarely and only on small areas to make spatial analyses. Thanks to geographic information systems it is now possible to adequately treat the large quantity of useful data that these registers collect [Agnoletti 2009; Campana 2000; Norunn 2007].

The conversion into digital format of the maps of the Tuscany cadastral sections preserved in the regional state Archives, was carried out within the project "Castore", thanks to an agreement deal aimed at the diffusion of regional historical cadastral data, signed by the Tuscany Region and the Italian ArtsCulture Ministry. The digital maps concerning the study area, were made available for the research by the Siena Province, who oversaw the process of map georeferencing of the whole Siena province.

Even though in georeferencing residual errors are difficult to quantify [Ciali 2009], in our investigation we preferred to use these already geo-referenced maps, in order to facilitate any enhancement of data layers obtained by our work for the regional database.

According to the methodology adopted, the computerisation of the cadastral sections consisted in two stages:

- on screen vectorisation, in a GIS environment, for parcel boundary network, settlement system, toponyms, roads, and hydrographs

- the allocation of information about parcel number, land owners and land use to each parcel, linking data from the "Tavole Indicative" to vector digital maps.

The layers thus obtained represent the landscape of the early nineteenth century.

\subsection{Land survey}

Surveys and measurements were carried out in a test area chosen as representative of the Montagnola Senese. It is a portion of about 300 hectares called Monte Maggio chosen for its high density of estate complexes and historical values. In fact there are 8 historical holdings: Campassini, S.Giovanni, La Ripa, Il Mandorlo, Il Gallinaio, Ebbio, La Camminata, Casetta. The altitude of the area varies from 200 to $450 \mathrm{~m}$. 
Some preliminary analyses were carried out to gain information to optimize the planning of fieldwork and to conduct an initial screening aimed to know the test area.

It is well known that the stones collected during field tillage were heaped around agricultural areas so that they could easily be used to build walls to enclose fields and protect crops. This type of agricultural landscape corresponds to the one called "Campi Chiusi" or enclosed fields [Sereni 1962]. In that regard, a first analysis was made to identify all the agricultural parcels in the 1825 Cadastre. After analyzing the property breakdown of that time, the boundary lines have been identified where one could assume the presence of walls acting as property limits. During this phase we also examined the presence in the historical cadastral parcels of both physical geographical boundaries, identified along either the hydrographic network or ridge lines, and infrastructural boundaries made of historical roads.

Then, the area covered by the surveys was divided into portions of about the same extent, in order to produce detailed large-scale maps to use during fieldwork. The scale ratio chosen for these maps is the same of the base map, i.e.1:5000. We considered it suitable to easily represent land use and ownership polygons relating to 1825 , hydrographic network, topographical data, as well as the 2007 aerial photos.

In the planning phase of the surveys, the problems associated with using the GPS receiver in a forest environment were also to be considered. In fact, the performances of precision claimed by the manufacturers of satellite radio positioning equipment are related to perfect operating conditions with good visibility of the satellite constellation, not covered by foliage; these performances do not correspond to actual conditions of receivers in wooded areas. According to other studies with the same receiver, we can estimate as an average precision in similar canopy conditions a value of about 4-5m [Bonavita 2009]. Because of these limitations we did not prefer to carry out tracking measurements and to statically survey instead the points for walls and roads to map. Positioning uncertainties were taken into account in the analysis, by setting a wide buffer around the lines of the walls surveyed.

The equipment used for the surveys consisted of a GPS device (Garmin 76), thematic maps of the test area, survey forms and a digital camera. The GPS point survey was conducted by setting the device in order to average 30 fixes per point feature positioning. The survey form was designed to note:

- the landmark identification number;

- a brief description of the artifacts analyzed and of the environment surrounding each landmark;

- the photograph documentation reference.

The adopted methodology planned to follow the identified self-standing dry stone walls for their entire length, and to make GPS positioning approximately every $20 \mathrm{~m}$. During the survey we also noted any lateral wall junctions, the presence of roads or other arti- facts which could not directly be mapped with a limited number of positionings. All these features had to be surveyed at a later time. During this stage, we noted that most of the walls stretched in a zigzag line (consisting of straight segments linked together to form corners). In these wall sections a specific method was used where only the corner points were surveyed. The methodology planned to regularly update the LIS with data collected in fieldwork, in order to support surveyors with updated maps recording the distribution of all artifacts already surveyed. As for the roads it was possible to detect traces of historical roads which are now abandoned and very often hidden by vegetation.

\subsection{Data analysis}

After downloading the coordinates of the gathered points from the GPS device, we converted them from WGS84 datum (commonly used by GPS devices) to the Gauss-Boaga coordinate reference system to obtain an accurate layer, which could be superimposed on to the other layers in the GIS.

The first goal of this work was the reconstruction through digitization of the walls' spatial distribution and it was achieved by following the layer of the points and their descriptions, collected in the survey forms.

The walls surveyed were ascribed to two distinct classes, i.e. the walls along roadsides (Type 1) and the ones in the remaining area (Type 2). We thought it convenient to make such a distinction because walls located along the roads are closely related to them, require specific analysis and are largely outside the objectives of this work.

The pictures taken during fieldwork surveys were collected, catalogued in a database and connected through hyperlinks to the segments of the related polyline, so that they could be easily consulted during the computer analysis. Furthermore, the slope of the land where walls were surveyed was calculated by slope analysis, a function available in most GIS packages.

Then, according to the methodology developed, we compared wall spatial distribution to the land arrangement of the early nineteenth century, reconstructed from the analysis of the documents of the Tuscany General Cadastre. In order to make such a comparison, it was necessary to assess the connection between wall polylines and the parcel boundary lines derived from vectorisation of historical maps. To take into account both of the following problems, i) the use of GPS in wooded areas, discussed above, and ii) the subsistence of residual errors in the georeferencing process of historical cadastral maps, a buffer zone was used around the lines of the walls. As a matter of fact georeferencing led to a result where errors can be found, as revealed by the authors, who claim that one can roughly quantify the errors, from minimum values at the points used as control points for georeferencing, 
to a maximum of $50 \mathrm{~m}$ in extreme cases. The same also found errors, presumably due to cadastral map construction, that increase in direct proportion to the distance from larger towns and, in general, are greater where the area is more rugged, this being the case of the area analyzed [Ciali 2009]. This task was performed by testing different buffer sizes gradually increasing and choosing $20 \mathrm{~m}$ to achieve a good agreement.

Next we drew a polyline of the cadastral boundaries included in the buffer area, excluding the segments that showed a different direction compared to the wall line where the buffer had been set. Within the attribute table of the polyline so obtained, called " Walls Forced on the parcel boundary lines" (herein Forced Walls), we reported for each record, the information on land use and the ownership of the parcels that in the historical cadastre were divided by the same line. The output layer thus obtained represents the walls that, according to the adopted methodology, might have maintained their layout since the cadastral operations of the nineteenth century, when surveyor engineers of the Grand Duchy of Tuscany measured them as parcel boundaries.

The "Forced Walls" data layer was used to perform the functional and historical analysis of the walls to understand their role in the past land management. By analyzing the historical Land Uses from a cultivation perspective, through aggregative operations, two subareas were detected, the agricultural and the forestry one. In these sub-areas we went on to analyze the functions of the walls according to the sectors they divided. Similarly, we analyzed the functions performed by the walls in connection to the property that they presumably divided in the historical cadastre.

\section{Results and discussion}

The survey conducted in the Monte Maggio study area allowed us to map approximately $16.835 \mathrm{~m}$ of self-standing dry stone walls, of which, $15.048 \mathrm{~m}$ were found in fairly good condition and $1.787 \mathrm{~m}$ in a poor state of preservation, in great need of maintenance but with their track still recognizable on the ground. The global density of these walls, taking into account the 300 ha of the investigation area, is about $56 \mathrm{~m} / \mathrm{ha}$.

For each part of wall analyzed, we collected and catalogued the survey forms with geographical references and environmental characters, each one accompanied by photographic documentation.

We considered an important result that $14.354 \mathrm{~m}$ ( $85 \%$ of the total) of walls surveyed has been found to correspond to the cadastral boundary lines.

The general map of the investigation area (Fig. 1), reconstructed from the analysis in a GIS environment, highlights the connection between most of the wall polylines and the historical cadastral parcel boundary lines.

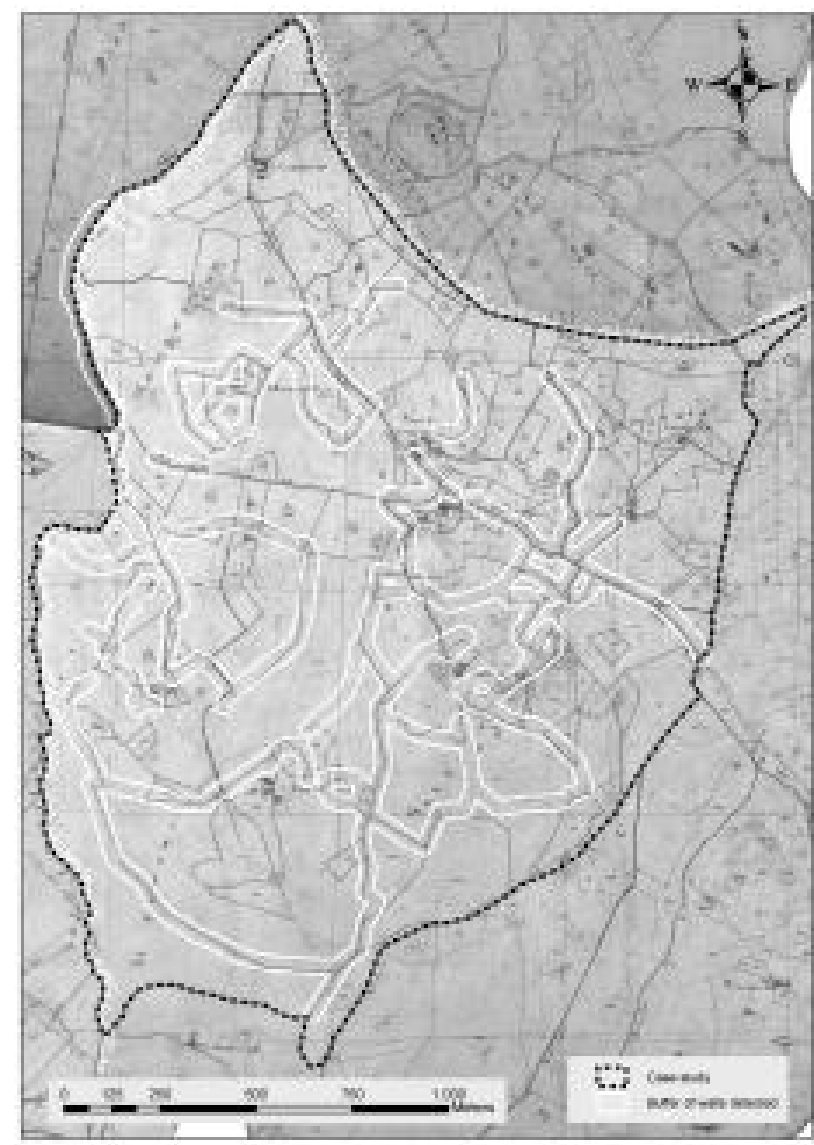

Fig. 1 - General map of the case study showing the matching between Cadastral boundary and the self-standing dry stone walls surveyed where the buffer has been set up.

Starting from the morphology of the investigation area we analysed the wall distribution according to the land slope. Figure 2 shows the results of the slope analysis, it is worth noting that most of the walls were built on land with a slope of less than $20 \%$ and only a small percentage on land steeper than $30 \%$.

As for the functional historical analysis (Fig. 3),

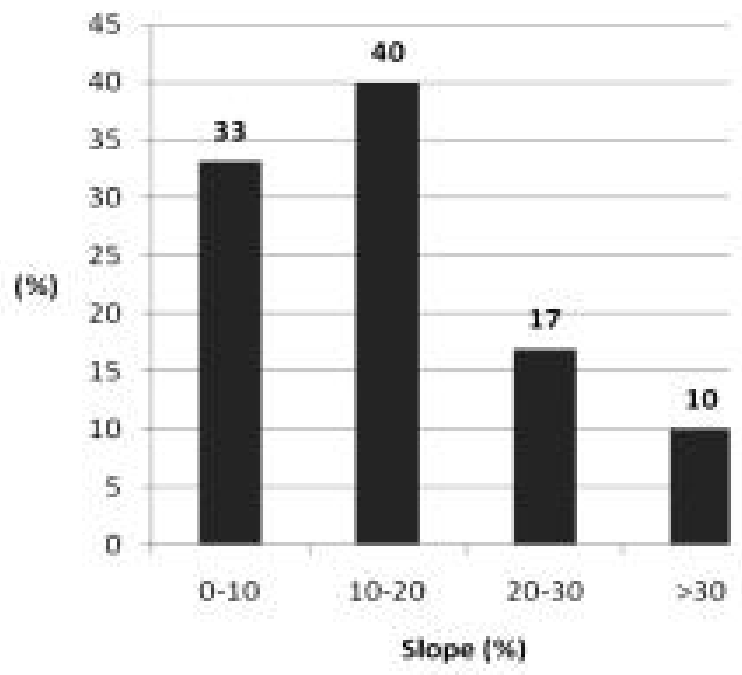

Fig. 2 - Percentage distribution of self-standing walls according to the slope of the land 


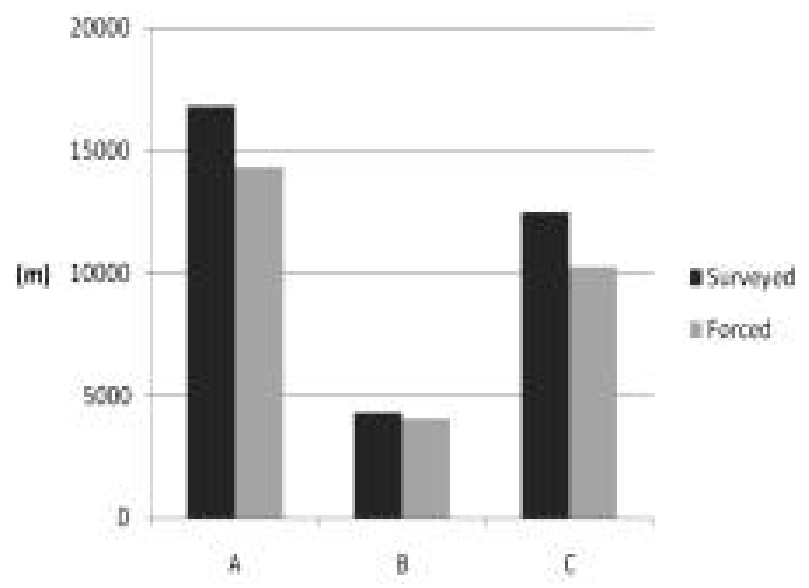

Fig. 3 - Length of self-standing dry stone walls. The surveyed and the forced ones: Total Walls (A), Roadside walls (B), Other Walls (C).

we have noted that the "Forced Walls" reach a total length of $14.354 \mathrm{~m}$, of which $4.105 \mathrm{~m}$ are associated to roads of historical importance (Forced walls 1), and $10.250 \mathrm{~m}$ are spread in the rest of the investigation area (Forced walls 2).

Given that the total length of the historical cadastral boundary lines that break down the investigation area into parcels is $53.164 \mathrm{~m}$, which shortens to $38.109 \mathrm{~m}$ when removing the lines identified both by a physical geographical criterion along the streams, and by an infrastructural criterion along the roads, we calculated a wall index of cadastral boundaries, by comparing the two lengths of Forced walls 2 and cadastral boundaries. In particular we obtained the result of $26,9 \%$. That means that about $27 \%$ of the historical cadastral parcel boundaries, not identified by easily traceable physical geographical or infrastructural boundaries, are now made of self-standing dry stone walls. We should also consider that about two hundred years have passed since the historical cadastral survey. In this span of time the walls have lost much of their importance and may have been significantly reduced in terms of length and type diversity, for example their paths may have been changed and their stones used for other buildings.

The reconstruction of the landscape of landed estates for the early nineteenth century, (Fig. 4 and Tab. 1) shows that this area was divided into four main properties, and only $5 \%$ of the land belonged to other owners, who possessed each one an area of less than 5ha. The results of the Forced walls 2 distribution analysis, according to the properties that they divided in the nineteenth century, reveal that these structures did not only perform a function of property limit, but were also used to establish a framework system inside the properties. In fact, the analysis results show that $47 \%$ of the walls divided lands of the same owner and $53 \%$ identified the boundary of two different properties.

The analysis of the land use surfaces in the early nineteenth century, summarized in Table 2 and reported in Figure 5, shows that most of the area was wood- land (mainly holm oak forest and oak forest), and that about $25 \%$ of the territory was occupied by various kinds of agricultural areas.

The results of the functional historical analysis of the Forced walls 2, relating to the land uses that they divided in the early nineteenth century (Fig. 6), show that the walls performed two main functions, in

\begin{tabular}{|c|l|c|c|}
\hline & \multirow{2}{*}{ Land Owners in 1825 } & \multicolumn{2}{|c|}{ Sarface area } \\
& & 125 & 41 \\
\hline 1 & Griccioli & 82 & 27 \\
\hline 2 & Nardi & 44 & 14 \\
\hline 3 & Bargagli & 41 & 13 \\
\hline 4 & Brancadori & 8 & 2 \\
\hline 5 & Picve di S. Maria assunta & 3 & $<1$ \\
\hline 6 & Bianchi & 3 & $<1$ \\
\hline 7 & Palmicri & 1 & $<1$ \\
\hline 8 & Pamigiani & 1 & $<1$ \\
\hline 9 & Bartalini & 0.2 & $<1$ \\
\hline 10 & Conservatono S. Maria & & \\
\hline
\end{tabular}

TABLE 1 - Land owners in 1825. It is evident that there were four main owners.

\begin{tabular}{|c|l|c|c|}
\hline $\mathbf{N}$ & \multicolumn{1}{|c|}{ Land Use in 1825 } & ha & $\%$ \\
\hline 1 & Sodo olivato & 1 & $<1$ \\
\hline 2 & Pastura & 20 & 3 \\
\hline 3 & Lavorativo nudo & 14 & 5 \\
\hline 4 & Lavorativo vinawo & 10 & 3 \\
\hline 5 & Lavorativo olivato & 40 & 13 \\
\hline 6 & Lavorativo vitato, olivato & 1 & $<1$ \\
\hline 7 & Lavorativo gelsato & 1 & $<1$ \\
\hline 8 & Bosco & 3 & 1 \\
\hline 9 & Bosco misto & 1 & $<1$ \\
\hline 10 & Bosco cedeo & 6 & 2 \\
\hline 11 & Bosco kcciato & 32 & 10 \\
\hline 12 & Bosco quefciato & 1 & $<1$ \\
\hline 13 & Bosco a palina & 5 & 2 \\
\hline 14 & Bosco a querci & 162 & 53 \\
\hline 15 & Bosco a lecci & $<1$ \\
\hline 16 & Bosco con quercie & & 5 \\
\hline
\end{tabular}

TABLE 2 - Land use in 1825 . About $70 \%$ of the test area was woodland. The most represented use is the "Bosco a lecci" (holm oak forest). 


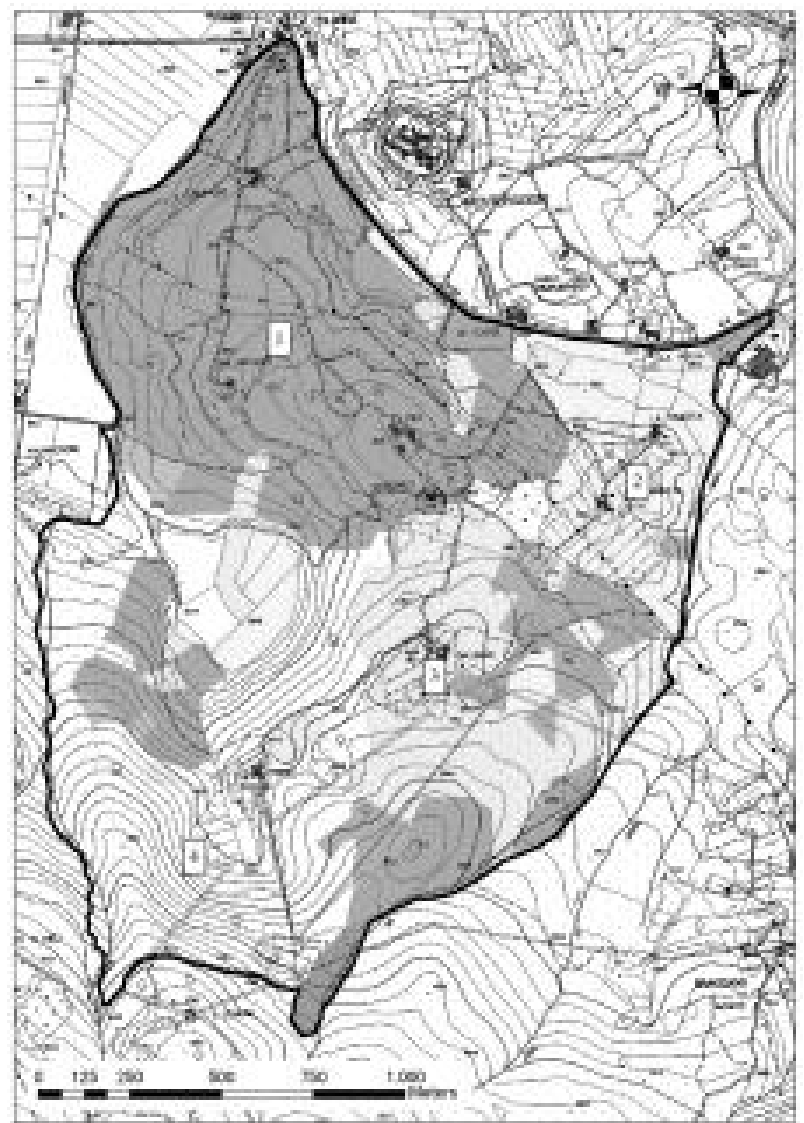

Fig. 4 - Land property map of 1825 . The numbers refer to land owners shown in tab. 1.

roughly the same proportion: they separated an agricultural area from a wooded area or separated two wooded areas; only a small percentage of the walls separated two agricultural areas.

Apart from protecting agricultural fields, the walls were utilized for the management of woodlands. More about this later function emerges from the cross-check of both the functional analyses, relating to the property and the land uses, mentioned above. Following the development of agricultural techniques, it should also be taken into consideration that the cultivated areas have undergone well-known infrastructural changes (such as deviation of roads, changes of land use or of management system) [Casanova 2007].

Table 3 shows the results obtained from the functional historical analysis of the Forced walls 2 on the basis of two parameters, land use and property, both separated and analyzed simultaneously. The table shows that the major function performed by the walls is as inside woodland boundary. This result seems to suggest that self-standing dry stone walls were used to identify property boundaries in forested areas and to prevent cattle from straying into agricultural areas.

An interesting figure in Table 3 is the $15.4 \%$ of walls that divide two forested areas belonging to the same property owner. This percentage seems to confirm that self-standing walls were used to partition the wooded area of each property. Besides marking the

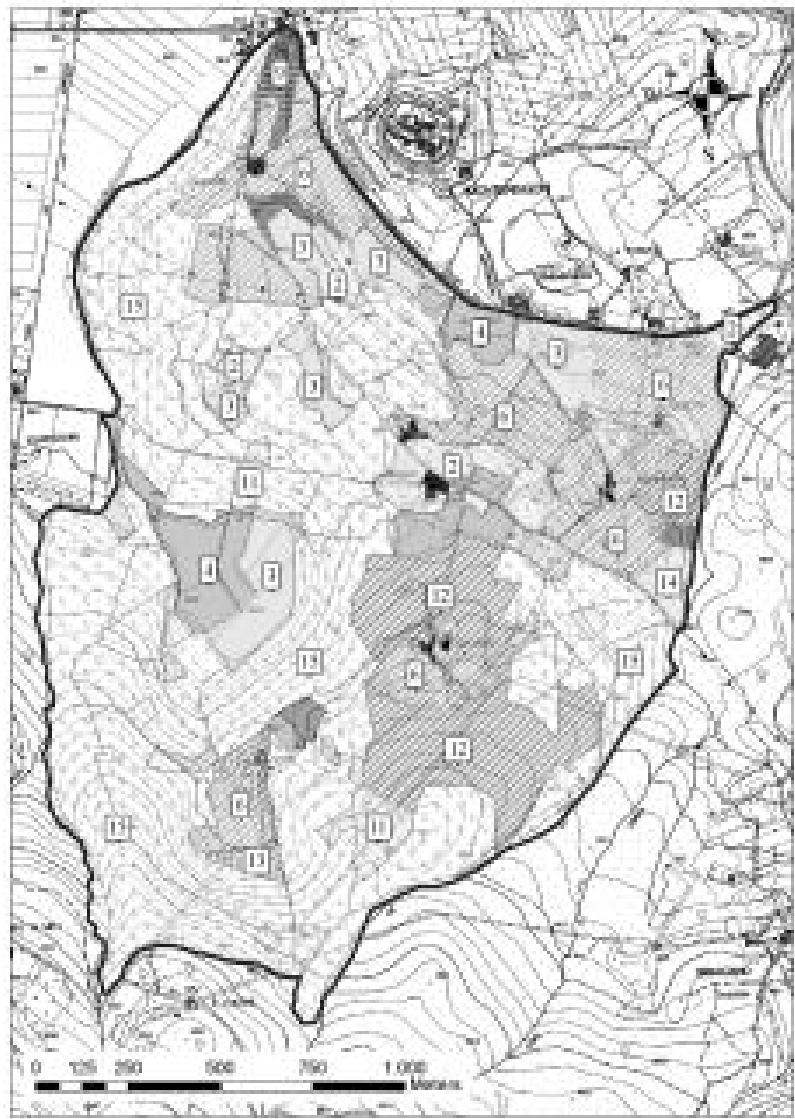

Fig. 5 - Land use map of 1825 . The numbers refer to land use as shown in the first column in Table 2 .

boundaries of the property, in our opinion the walls located inside the wooded area were used to partition woodlands. This feature seems to be related to the livestock management, as shown in "Il Padrone contadino, Osservazioni agrario critiche del canonico Ignazio Malenotti, Pievano di Montauto, Comizio Agrario di Siena, Colle 1815" (The master farmer. Critical agrarian Comments of Canon Ignazio Malenotti, parish priest of Montauto, Agrarian Societies of Siena, Colle 1815).

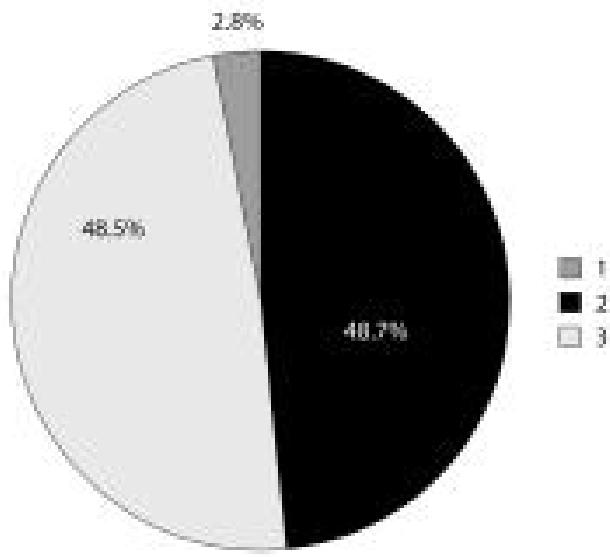

Fig. 6 - Percentage distribution of Forced walls referred to the agricultural or forest sector: 1 - Dividing two agricultural areas; 2 - Dividing an agricultural from a wooded area; 3 - Dividing two wooded areas. 


\begin{tabular}{|c|c|c|}
\hline $\begin{array}{c}\text { Self-standing dry } \\
\text { stone walks } \\
\text { dividing: }\end{array}$ & $\begin{array}{c}\text { bud belonging to } \\
\text { the same ewner }\end{array}$ & $\begin{array}{c}\text { land belonging to } \\
\text { differeat ow hers }\end{array}$ \\
\hline $\begin{array}{c}\text { two agricultural } \\
\text { areas }\end{array}$ & $2.1 \%$ & $0.7 \%$ \\
\hline $\begin{array}{c}\text { agricultural arcas } \\
\text { trom wooded areas }\end{array}$ & $29.2 \%$ & $19.4 \%$ \\
\hline \\
two wooded areas
\end{tabular}

TABLE 3 - Percentage distribution of forced walls compared to land use sectors and land ownership of 1825 .

The analysis of the self-standing dry stone wall distribution in the study area, shows that these artifacts were strictly linked to the various activities conducted in the holdings. Indeed, the use of this type of artifact to partition agricultural and forestry land, is particularly evident in Figure 7 and Figure 8, which concern "S. Giovanni" and "Ebbio" holdings.

Another important result emerged from the historical cadastral maps analysis, that is the identification
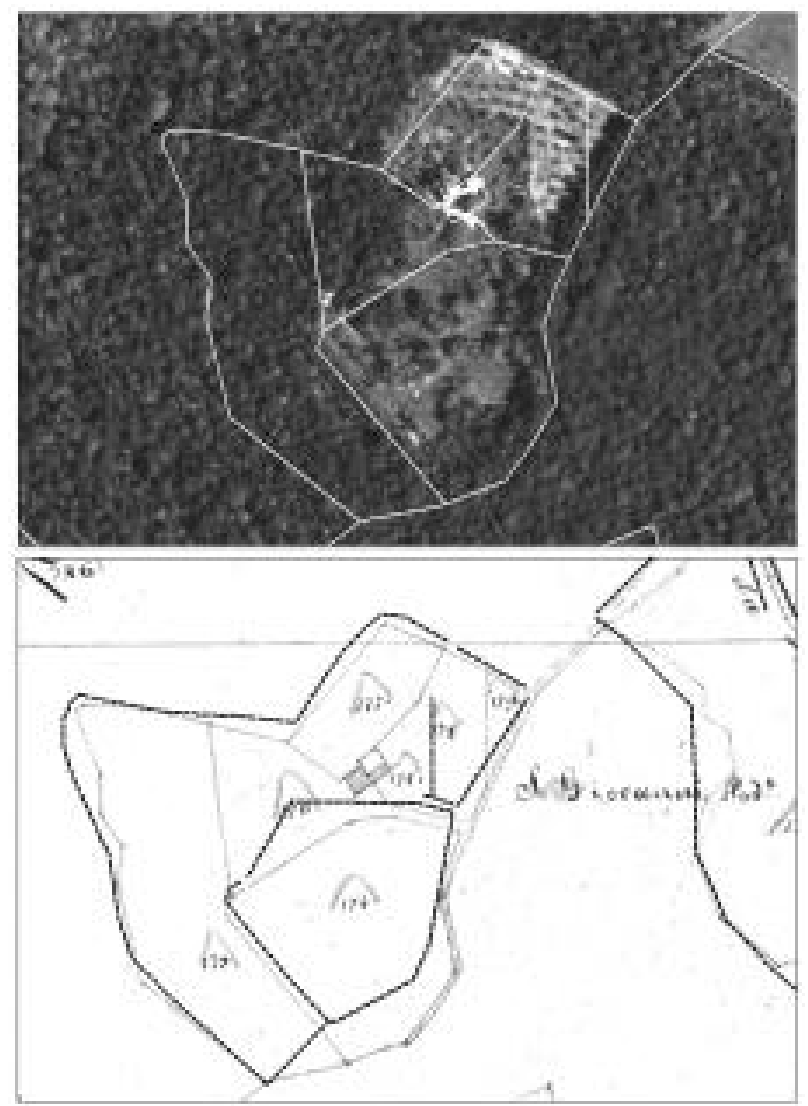

Fig. 7 - S. Giovanni holdings. The picture at the top shows the overlapping, in the GIS environment, of the historical cadastral parcel boundaries of 1825 , with the aerial photo of 2007 . The other picture shows the path of the surveyed walls (marked by a black dotted line) overlapped with the historical cadastral map. of road sections paved with stone and self-standing dry stone walls located along the roadway sides. These road sections are often hidden by vegetation and not used for travelling. The state of neglect has probably caused the preservation of the historical stone artifacts along these roadways.

During the surveys others important structures built in dry stone were found and georeferenced. They confirm the historical and cultural value of dry stone artifacts in this local context and are useful to reconstruct the past territorial management in the area: terraces; retention basins fed by meteoric water, surrounded by low dry stone walls, which, according to the accounts collected, until a few decades ago were used for the watering of grazing livestock; dry stone lunettes in support of olive trees and charcoal areas; small stone bridges (Fig. 9); works of water drainage, such as stone-lined conduits. A dry stone covered cistern has also been reported near the Ebbio Holding.

In light of the results obtained in the test area, the methodology has proved suitable for the purpose for which it was developed. It also made it possible to detect historical roads fallen into disuse, hidden by tree vegetation.

The preliminary surveys carried out to develop the methodology confirmed the widespread presence of self-standing dry stone walls in much of the Montag-
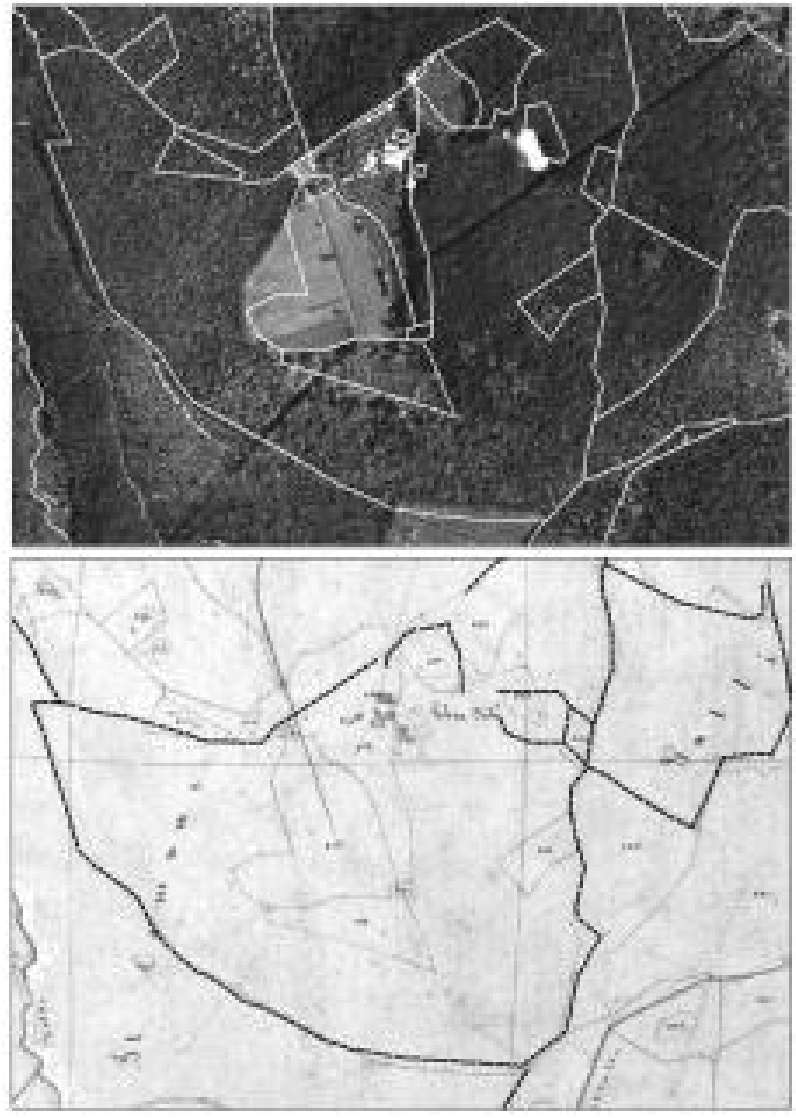

Fig. 8 - Ebbio holdings. The picture on the top shows the overlapping of the historical cadastral parcel boundaries of 1825, through an aerial photo of 2007. The other picture shows the path of the surveyed walls (marked by a black dotted line) overlapped with the historical cadastral map. 


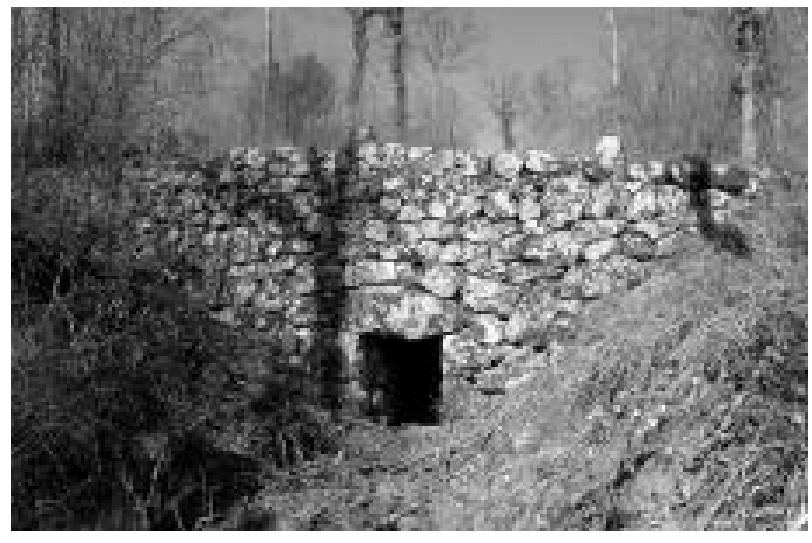

Fig. 9 - Stone bridge.

nola Senese territory (Fig. 10), with higher densities around the historical estate-complexes. In addition, the historical cadastral maps analyzed at a local level for the whole of the Montagnola area, show that the parcel division around these historical estate-complexes is similar to the test area.

Following these considerations, we believe that this methodology may be successfully applied to the entire area of the SCI-SIR Montagnola Senese, and it may lead to build a detailed stock of knowledge about the distribution of these artifacts.

Since the Castore project has made it possible to computerize all the historical maps of the Leopoldian Cadastre, we believe that this trial methodology may be further implemented to study similar infrastructures in all the Tuscany region.

In agreement with local associations, the institutions responsible for land management of the Site of Community Importance "Montagnola Senese", could use this methodology of spatial analysis in support of rural development planning with the involvement of all citizens as has happened in other Italian regions [Regione Puglia 2009].

\section{Acknowledgments}

The authors wish to thank Prof. Pietro Piussi of the University of Florence and Dr. Antonio Gabrielli of the Italian Academy of Forest Sciences (AISF) for their precious suggestions.

\section{References}

Agnoletti M., Il Paesaggio come risorsa, Castagneto negli ultimi due secoli (Landscape as a resource, Castagneto in the last two centuries). Edizioni ETS, 2009.

Baldeschi P., Terrazzamenti e muri a secco nella provincia di Firenze: dieci anni dopo (Terraces and dry stone walls in the province of Florence: ten years later). Edizioni Polistampa, 2008.

Biagioli G., L'agricoltura e la popolazione in Toscana agli inizi dell'Ottocento (Tuscany Agriculture and population

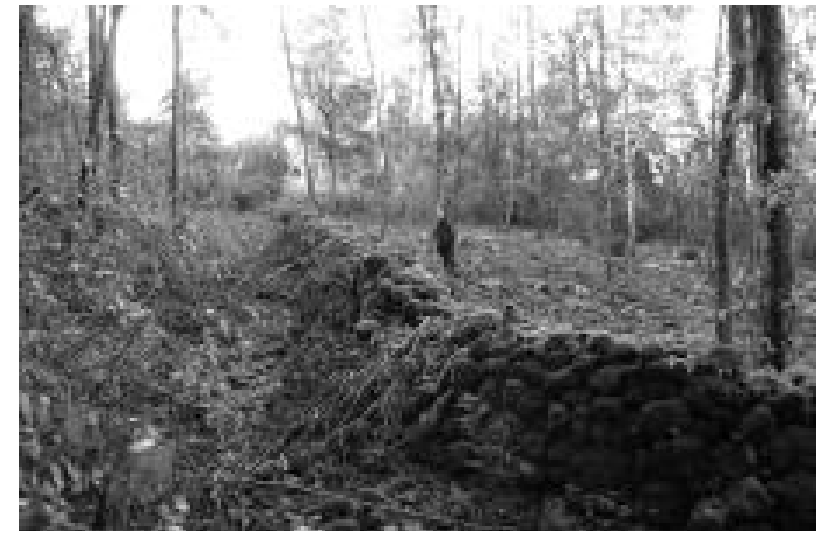

Fig. 10 - Section of self-standing dry stone wall made visible by forest harvesting activities.

in the early nineteenth century). Pacini editore, 1976.

Bollettino Ufficiale della Regione Puglia - n. 71 del (2009), AZIONE 1- Ripristino muretti a secco, MISURA 216 Sostegno agli investimenti non produttivi, ASSE IIMiglioramento dell'ambiente e dello spazio rurale, FEASR 2007-2013 Regione Puglia (Official Gazette of Puglia Region - n. 71 (2009). Action 1- Dry stone walls restoration, Measure 216 - Support to non productive investments, Improvement of rural environment).

Bonavita A., Pini L., Pellegrini P., Attendibilità del posizionamento planimetrico satellitare GNSS in ambito forestale con strumentazione GPS semplificata (Reliability of GNSS satellite horizontal positioning in forest environment by handheld GPS receivers). L'Italia Forestale e Montana, 2009, 64 (3), 185-195.

Cammarosano P., Monteriggioni storia architettura paesaggio (Monteriggioni history architecture landscape). Electa Editrice, 1983.

Cantile A., Toscana geometrica, La prima cartografia geodetica regionale e il contributo dell'Osservatorio Ximeniano (Geometric Tuscany. The first regional geodetic map and the contribution of the Ximeniano Observatory), Istituto Geografico Militare, 2008.

Carnasciali M., Le campagne senesi del primo '800 (The countryside of Siena in the early XIX century). Leo S. Olschki Editors, 1989.

Casanova P., Sorbetti Guerri F., La vita e le cacce dei contadini fra ottocento e novecento, quando si cacciava per vivere (The life and the huntings of the farmers between the nineteenth and twentieth centuries, when people hunted for a living). Edizioni Polistampa, 2007.

Ciali A., Comunicazione personale, Consorzio Terre Cablate, 2009.

Di Fazio S., I terrazzamenti viticoli della costa viola (The wine terraces of the purple coast ). Edizioni Polistampa, 2008.

Guidetti M., Storia dei sardi e della Sardegna. Vol. 4: L'Età contemporanea. Dal governo piemontese agli anni Sessanta del nostro secolo (History of Sardinians and Sardinia. Vol 4: The contemporary Age. From Piedmont Government to the Nineteen-Sixties). Jaca Book, 1990.

Monti M., Pellegrini P., Venturi L., Costruzioni rurali come strumenti produttivi: un approccio urbanistico diverso (Rural buildings as production tools: a different urban approach). Estimo e Territorio, 2006, 7/8, 24-28. 
Murray-Wooley C., Raitz K., Rock Fences of the Bluegrass (Perspectives on Kentucky's Past: Architecture, Archaeology, and Landscape). University Press of Kentucky, 1992.

Norunn Hamre L., Tage Domaas S., Austad I., Rydgren K., Land-cover and structural changes in a western Norwegian cultural landscape since 1865 , based on an old cadastral map and a field survey. Landscape Ecol 22: 1563-1574, 2007.

Sangiorgi F., Muri di sostegno a secco: aspetti agronomici, paesaggistici, costruttivi e di recupero. Conclusioni (Retaining dry walls: agronomic, landscape, construction and recovery aspects. Conclusions). Edizioni Polistampa, 2008.

Sangiorgi F., Branduini P., Calvi G., Linee guida per il recupero, Muri a secco e terrazzamenti nel parco dell'Adamello (Guidelines for the recovery, dry stone walls and terraces in the Adamello park). Fiordo s.r.l, 2006.

Sereni E., Storia del paesaggio agrario Italiano (History of the Italian agricultural landscape). Editori Laterza, 1962.

Stopani R., Guida ai percorsi della via Francigena in Toscana (Guide to the Francigena paths in Tuscany). Le lettere, 1995.

\section{Web sites}

Campana S., Greppi C., Un prototipo di elaborazione informatica del catasto leopoldino: il Comune di Murlo in provincia di Siena (A prototype of computerized processing of the Leopoldian cadastre: the Murlo municipality in the province of Siena). University of Siena, 2000:

http://www.storia.unisi.it/index.php?id=344

(accessed May 2010)

Regione Toscana. Progetto CASTORE (CAtasti STOrici REgionali) project: http://web.rete.toscana.it/castoreapp/

(accessed May 2010)

\section{SUMMARY}

The aim of this paper is to highlight the development of a methodology for studying linear infrastructures such as dry stone walls, characteristic of an earlier land management in the Siena countryside. The study area on which this methodology was tested is located in the Site of Community Importance (SCI) "Montagnola Senese". It was chosen as an example of a historical form of agricultural and forest land management, partly related to the key presence of the above mentioned artifacts. This methodology was based on the analysis of a historical cadastre and the concurrent construction and updating of a L.I.S. (Land Information System) processed in a GIS environment. In order to compare 1825 data about land use, land ownership and parcel boundaries of the current walls were surveyed during fieldwork through GPS handheld equipment. The results show quite a good correspondence between wall lines and cadastral parcel boundary lines, mostly in the woodland. The analysis of the study area brings out that the walls were designed to carry out different functions such as property boundary, to enclose fields and defend them from the entrance of livestock grazing in the woodland, and subdivide a same land property in different management portions both as cultivated fields and as woodland.

Keywords: Linear dry stone infrastructures, Dry stone walls, GIS, Historical cadastre, Montagnola Senese. 
